\title{
Sphenoorbital Meningioma
}

National Cancer Institute

\section{Source}

National Cancer Institute. Sphenoorbital Meningioma. NCI Thesaurus. Code C5285.

A mening ioma that affects the sphenoorbital region. 